\title{
PERAN PENGAWASAN INTERNAL DALAM MEWUJUDKAN PEMERINTAH DAERAH YANG BAIK
}

\author{
H. Achmad Fauzi *
}

\begin{abstract}
Implementation of local government as regulated by Law Number 23 Year 2014 contains three functions. The first function is the planning of activities of local government tasks that are acceded by the Regional Development Planning Agency (Bappeda), the second function is the implementation of the tasks of local government that are represented and implemented by the Regional Device Organization (OPD) in the local government, and the third function is supervision the implementation or implementation of local government implemented by the Regional Inspectorate as the supervisor of the local government. Internal supervision (Inspectorate) is formed in order for the implementation of local government tasks that are run by all existing regional devices can run well, effective, efficient and effective on target according to predetermined plans. Therefore, the Inspectorate's role in overseeing the tasks of all the Regional Apparatus Organizations in the local government is very important. In order to obtain an effective supervision, it is necessary to meet two principles of supervision, namely; first, is the existence of a specific plan and the giving of instructions; second, giving clear authority to subordinates. The first basic principle is a must, because the plan is a standard, a measure of the work performed by subordinates. If this principle is well executed, then the implementation of good local government will be achieved well too.
\end{abstract}

Keywords: Internal Control, Good Local Government

\section{PENDAHULUAN}

Di era reformasi pemberian otonomi yang seluas-luasnya kepada daerah diarahkan untuk mempercepat terwujudnya kesejahteraan masyarakat melalui peningkatan pelayanan, pemberdayaan, dan peran serta masyarakat. Di samping itu melalui otonomi yang luas, daerah diharapkan mampu meningkatkan daya saing dengan memperhatikan prinsip demokrasi, pemerataan, keadilan, keistimewaan dan kekhususan serta potensi dan keanekaragaman daerah dalam sistem Negara Kesatuan Republik Indonesia.

* H. Achmad Fauzi, Dosen Fakultas Hukum UNTAG Semarang, dapat dihubungi melalui email: achmadfauzi957@yahoo.co.id (penjelasan angka 1 UU No.23 Tahun 2014).

Dalam penyelenggaraan pemerintahan daerah, Kepala Daerah mempunyai kedudukan yang penting dan menonjol pada suatu struktur pemerintahan daerah. Kepala Daerah adalah orang pertama dan paling utama dalam mengkoordinasikan pada proses penyelenggaraan jalannya pemerintahan daerah. $^{1}$

Kepala Daerah adalah jabatan politik dan jabatan publik yang bertugas memimpin birokrasi, dan menggerakkan jalannya roda pemerintahan. Fungsi-fungsi

1 Sarundajang, 2002, Pemerintahan Daerah Di Berbagai Negara, Pustaka Sinar Harapan, Jakarta, hlm. 126. 
pemerintahan daerah terbagi atas perlindungan, pelayanan publik dan pembangunan. Kepala daerah menjalankan fungsi pengambilan kebijakan ketiga fungsi pemerintahan tersebut. Dalam konteks struktur pemerintahan, kepala daerah adalah kepala eksekutif di daerah. ${ }^{2}$

Oleh karena itu, maka di dalam birokrasi Pemerintahan, khususnya birokrasi pemerintahan daerah diperlukan kepemimpinan kepala daerah dan kepala dinas instansi terkait / Organisasi perangkat Daerah (OPD) serta aparatur pemerintah daerah lainnya memiliki integritas dan loyalitas, kemampuan, kreatif, inovatif, responsif, jujur, amanah, demokratis, dan taat azas, serta memiliki wawasan kepemimpinan yang berkarakter kearifan lokal. $^{3}$

Reformasi birokrasi dalam penyelenggaraan kegiatan pemerintahan dan pelayanan publik diarahkan untuk menciptakan kinerja birokrasi yang profesional dan akuntabel. Birokrasi dalam melakukan berbagai kegiatan perbaikan pelayanan diharapkan lebih berorientasi pada kepuasan pelanggan, yakni masyarakat pengguna jasa. Kepuasan total dari masyarakat pengguna jasa tersebut dapat dicapai apabila birokrasi pelayanan menempatkan masyarakat sebagai peng guna jasa dalam memberikan pelayanan. Perubahan paradigma pelayanan publik tersebut diarahkan pada perwujudan kualitas pelayanan prima kepada publik,

2 Joko Priatmoko, 2005, Pemilihan Kepala Daerah Langsung, Filosofi, Sistem, dan Problema Penerapan di Indonesia, Pustaka Pelajar, Jogjakarta, hlm, 203.

3 Kearifan lokal adalah sikap, pandangan, dan kemampuan suatu komunitas di dalam mengelola lingkungan rohani dan jasmaninya yang memberikan kepada komunitas itu daya tahan dan daya tumbuh di dalam wilayah di mana komunitas itu berada. Dengan kata lain, kearifan lokal adalah jawaban kreatif terhadap situasi geografis-politis, historis, dan situasional yang bersifat lokal. Saini dalam R. Cecep Eka Permana, 2010, Kearifan Lokal Masyarakat Baduy Dalam Mitigasi Bencana, Wedatama Widya Sastra, Jakarta, hlm 1 melalui instrumen pelayanan yang memiliki orientasi pelayanan lebih cepat, lebih baik, dan lebih murah. ${ }^{4}$

Namun mentalitas dan budaya kekuasaan ternyata masih melingkupi sebagian besar aparat birokrasi pada masa reformasi. Kultur kekuasaan yang telah terbentuk semenjak masa birokrasi kerajaan dan kolonial ternyata masih sulit untuk dilepaskan dari perilaku birokrasi aparat atau pejabat birokrasi. Masih kuatnya kultur birokrasi yang menempat kan pejabat birokrasi sebagai penguasa dan masyarakat pengguna jasa sebagai pihak yang dikuasai, bukannya sebagai pengguna jasa yang seharusnya dilayani dengan baik, telah menyebabkan perilaku pejabat birokrasi menjadi bersikap acuh dan arogan terhadap masyarakat. ${ }^{5}$

Kecenderungan perilaku birokrasi yang masih tetap korup dan belum megubah kultur pelayanan yang baik kepada publik, semakin terlihat pada masa reformasi. Birokrasi di Indonesia saat ini masih dikuasai oleh kekuatan yang begitu terbiasa berperilaku buruk selama puluhan tahun, birokrasi tidak hanya mengidap virus kleptomania, tetapi virus anti reformasi. Virus kontra produktif dalam birokrasi tersebut sangat berpotensi untuk terjadinya penularan ke seluruh jaringan birokrasi pemerintah, baik ditingkat pusat maupun ditingkat daerah, baik dikalangan pejabat tinggi maupun dikalangan aparat pada tingkat bawah. Masih belum efektifnya upaya penegakan hukum dan kontrol publik terhadap birokrasi pemerintah, desertai masih lemahnya pula sistem kontrol internal birokrasi, penyebab berbagai tindakan penyimpangan yang dilakukan aparat birokrasi pemerintah masih terus berlangsung. ${ }^{6}$

Parameter pemerintahan yang baik (good government) yang berupa pelayanan

4 Agus Dwiyanto dkk, 2008, Reformasi Birokrasi Publik di Indonesia, Gadjah Mada Univercity Press, Yogyakarta, hlm, 223-224.

5 Agus Dwiyanto, dkk, ibid, hlm, 225.

6 Agus Dwiyanto, dkk, ibid, hlm, 227. 
kepada masyarakat dan pembangunan, pemberdayaan warga masyarakat dalam pembangunan, belum sepenuhnya dicapai oleh kinerja pemerintah daerah. Hal itu menandakan lemahnya fungsi pengawasan terhadap jalannya pemerintahan daerah, khususnya pengawasan internal pemerintah daerah selama ini. ${ }^{7}$ Di samping itu dalam penyelenggaran pemerintahan daerah, juga masih terjadi adanya kurang memahami dengan baik dan benar secara komprehensif tentang makna otonomi daerah, kurang memahami tentang hak dan kewajiban dalam penyelenggaraan pemerintahan daerah oleh para penyelenggara pemerintahan daerah. Selain hal tersebut juga masih ada kepemimpinan daerah yang di dalam pengembilan kebijakan penyelenggaraan pemerintahan daerah belum berorientasi pada pengembangan pemabangunan daerah yang berwawasan pada kearifan lokal secara demokratis dan taat asas.

Menurut Saldi Isra yang dikutip oleh Lukman bahwa, menjamurnya korupsi di daerah dapat dilihat melalui tiga persoalan penting. Pertama, program otonomi hanya terfokus kepada pelimpahan wewenang dalam pembuatan kebijakan, keuangan, dan administrasi dari pemerintah pusat ke daerah, tanpa disertai pembagian kekuasaan kepada masyarakat. Kedua, tidak ada institusi negara yang mampu mengontrol secara efektif penyimpangan wewenang di daerah. Hubungan pusat dengan daerah hanya fungsional, yaitu hanya kekuasaan untuk memberikan policy guidance kepada pemerintah daerah tanpa diikuti oleh pengawasan yang memadai. Ketiga, legeslatif daerah gagal dalam menjalankan fungsinya sebagai lembaga kontrol. Justru sebaliknya terjadi kolusi yang erat antara pemerintah daerah dan DPRD sehingga kontrol terhadap penyelenggaraan pemerintahan daerh

7 Sedarmayanti, 2003, Good Government Dalam Rangka Otonomi Daerah, Mandar Maju, Bandung, hlm, 169. tidak terjadi, sementara kontrol dari kalangan civil society masih lemah. ${ }^{8}$

Sedangkan menurut Reydonnyzar Moenek ada beberapa hal yang mengakibat kan jumlah kepala daerah yang tersangkut kasus korupsi terus meningkat. Peratama, latar belakang kepala daerah di tanah air sengat beragam. Mulai birokrat, politisi, pengusaha, hingga artis. Dari latar belakang yang beragam ini banyak diantara kepala daerah yang pemahaman dan kemampuan tentang birokrasi sangat kurang, terutama tentang sistem keuangan daerah. Meraka akhirnya terjebak dalam kasus korupsi lantaran keputusan yang diambil ternyata melanggar ketentuan yang berlaku. Padahal sebenarnya mereka tidak berniat melakukan korupsi. Kedua, faktor sumber daya manusia (SDM) di daerah masih terbatas. Apalagi banyak ditemukan orang yang tidak berkompeten diberi jabatan strategis hanya karena yang bersangkutan menjadi tim sukses kepala daerah. Ketiga, adalah ada niat dari kepala daerah untuk melakukan korupsi. Kebanyakan pangkal dari persoalan korupsi kepala daerah adalah biaya kampanye pilkada yang sangat tinggi. jadi semua kepala daerah berlomba-lomba mengembalikan modal kampanyenya. Jika hanya mengandalkan gaji, mereka tidak akan dapat menutup modal. (Jawa Pos 16 April 2012).

Realitas ini sungguh sangat memperhatinkan, sebetulnya terjadinya korupsi yang merajalela di daerah, buruknya prilaku birokrasi, dan rendahnya disiplin pegawai birokrasi pemerintah daerah dalam menjalankan tugas dan kewajibannya dapat dicegah, jika fungsi lembaga pengawasan yang ada di daerah, khususnya lembaga pengawasan internal pemerintah daerah itu sediri dapat berfungsi dan bekerja dengan baik.

8 Lukman Santoso, Otonomi Yang Menyebarkan Korupsi, Jawa Pos 27 April 2011 


\section{Permasalahan}

Dari uraian latar belakang tersebut, maka permasalahan yang diangkat dalam tulisan ini adalah "Bagaimana peran lembaga internal (Inspektorat Daerah) dalam upaya mewujudkan pemerintahan daerah yang baik"?

\section{Pembahasan}

Penyelenggaan pemerintahan daerah yang diatur oleh Undang-undang Nomor 23 Tahun 2014 mengandung tiga fungsi. Fungsi pertama adalah perencanaan kegiatan tugas pemerintahan daerah yang diakili oleh Badan Perencana Pembangun an Daerah (Bappeda), fungsi kedua adalah pelaksanaan kegaiatn tugas pemerintahan daerah yang diwakili dan dijalankan oleh Organisasi Perangkat Daerah (OPD) yang ada di pemerintah daerah, dan fungsi yang ketiga adalah pengawasan penyeleng garaan atau pelaksanaan pemerintahan daerah yang dilaksanakan oleh Inspektorat Daerah sebagai pengawas interntal pemerintahan daerah.

Gerakan reformasi yang digulirkan yang diharapkan dapat memberikan pengaruh bagi penyelesaian berbagai persoalan bangsa selama masa pemerintahan Orde Baru berkuasa, seperti kasus korupsi, nepotisme dan kolusi, serta layanan pemerintah yang baik, belum dapat memberikan jawaban yang memuaskan masyarakat. Reformasi birokrasi dalam penyelenggaraan kegiatan pemerintahan dan pelayanan publik diarahkan untuk menciptakan kinerja birokrasi yang profesional dan akuntabel, sehingga akhirnya akan tercipta pemerintahan yang baik.

Istilah pemerintahan yang baik (good government) mulai dikenal luas setelah era reformasi berlangsung. Good government adalah merupakan praktek terbaik dalam proses penyelenggaraan kekuasaan negara dalam melaksanakan penyediaan public goods and service. ${ }^{9}$ Agar pemerintahan yang baik dapat menjadi kenyataan dan berjalan sebagai mana mestinya memerlukan komitmen dan keterlibatan semua pihak, yaitu pemerintah dan masyarakat. Good government yang efektif menutut adanya aligment (koordinasi) yang baik dan integritas, professional serta etos kerja dan moral yang tinggi. Prinsip pemerintahan yang baik meliputi : asas kepastian hukum, asas proporsionalitas, asas profesionalitas dan asas akuntabilitas. Terselenggaranya Good government merupakan prasyarat utama untuk mewujudkan aspirasi masyarakat dalam mencapai tujuan dan cita-cita bangsa serta Negara.

Parameter pemerintahan yang baik (good government) yang berupa pelayanan kepada masyarakat dan pembangunan, pemberdayaan warga masyarakat dalam pembangunan, belum sepenuhnya dicapai oleh kinerja Pemerintah Daerah. Hal itu menandakan lemahnya fungsi pengawasan terhadap jalannya pemerintahan daerah, khususnya pengawasan internal pemerintah daerah selama ini. ${ }^{10}$

Sedangkan yang dimaksud dengan pemerintah daerah adalah kepala daerah sebagai unsur penyelenggara Pemerintahan Daerah yang memimpin pelaksanaan urusan pemerintahan yang menjadi kewenangan daerah otonom. ${ }^{11}$

9 Pranarka, Pranarka, 1996, Pemberdayaan BUMN, Erisco, Jakarta, hlm. 12.

10 Sedarmayanti, 2003, Good Government Dalam Rangka Otonomi Daerah, Mandar Maju, Bandung, hlm, 169.

11 Pasal 1 ayat 12 UU No. 23 Tahun 2014, Daerah Otonom yang selanjutnya disebut Daerah adalah kesatuan masyarakat hukum yang mempunyai batas-batas wilayah yang berwenang mengatur dan mengurus Urusan Pemerintahan dan kepentingan masyarakat setempat menurut prakarsa sendiri berdasarkan aspirasi masyarakat dalam sistem Negara Kesatuan Republik Indonesia. Sedangkan yang dimaksud dengan Otonomi Daerah adalah hak, wewenang, dan kewajiban daerah otonom untuk mengatur dan mengurus sendiri Urusan Pemerintahan dan kepentingan masyarakat setempat dalam sistem Negara Kesatuan Republik Indonesia.( Pasal 1 ayat 6 UU No. 23 Tahun 2014), 
Menurut J. Kaloh pemimpin harus memiliki: Pertama, intuisi yaitu keterlibatan pemimpin dalam menatap situasi, mengantisipasi perubahan, mengambil resiko dan membangun kejujuran. Kedua, pandangan, yaitu keterlibatan pemimpin dalam meng imajinasikan suatu kondisi untuk memperbaiki lingkungan organisasi. Ketiga, diraih keselarasan, yaitu kemampuan memimpin untuk mengatahui dan memahami niali-nilai yang berkembang dalam organisasinya, nilainilai yang dimiliki bawahannya, serta dapat memadukan kedua nilai tersebut menuju organisasi yang efektif. Keempat, kepastian akan maksud dan arah tujuan. ${ }^{12}$

Dengan demikian dapat diartikan bahwa pemerintahan daerah yang baik adalah pemerintahan daerah yang di jalankan berdasarkan pada norma atau peraturan perundang-undangan yang mengaturnya secara konsisten dan bertanggung jawab dalam rangka mencapai tujuan negara yang dilandasi prinsip transparan, akuntabel, bersih, jujur dan amanah serta taat asas. Pemimpinnya mampu mengendalikan birokrasi pemerintahan daerahnya dengan baik dan terarah.

Istilah birokrasi seringkali dikaitkan dengan organisasi pemerintah, padahal birokrasi ciptaan Max Weber itu bisa terjadi baik diorganisasi pemerintah maupun organisasi non pemerintah. Di suatu perusahaan birokrasi itu bisa terjadi. Demikian pula, di suatu organisasi yang besar birokrasi akan terjadi. Birokrasi merupakan sistem untuk mengatur organisasi yang besar agar diperoleh pengelolaan yang efisien, rasional, dan efektif. Di Indonesia jika ada bahasan tentang birokrasi, maka persepsi orang tidak lain adalah birokrasi pemerintah.

12 J. Kaloh, 2009, Kepemimpinan Kepala Daerah. Pola Kegiatan, Kekuasaan, dan Perilaku Kepala Daerah dalam Pelaksanaan Otonomi Daerah, Sinar Grafika, Jakarta, hlm, 9-11
Birokrasi dengan segala macam cacatnya menjadi milik pemerintah. ${ }^{13}$

Masih belum efektifnya upaya penegakan hukum dan kontrol publik terhadap birokrasi pemerintah, desertai masih lemahnya pula sistem kontrol internal birokrasi, penyebab berbagai tindakan penyimpangan yang dilakukan aparat birokrasi pemerintah masih terus berlangsung. ${ }^{14}$

Sebetulnya terjadinya korupsi yang merajalela di daerah, buruknya prilaku birokrasi, dan rendahnya disiplin pegawai birokrasi pemerintah daerah dalam menjalankan tugas dan kewajibannya dapat dicegah, jika fungsi lembaga pengawasan internal (Inspektorat) yang ada di daerah bekerja dengan baik. Pengawasan intern (internal) adalah seluruh proses kegiatan audit, reviu, evaluasi, pemantauan, dan kegiatan pengawasan lain terhadap penyelenggaraan tugas dan fungsi organisasi dalam rangka memberikan keyakinan yang memadai bahwa kegiatan telah dilaksanakan sesuai dengan tolok ukur yang telah ditetapkan secara efektif dan efisien untuk kepentingan pimpinan dan mewujudkan tata kepemerintahan yang baik. ( Pasal 1 ayat (3) Peraturan Pemerintah Nomor 60 Tahun 2008 Tentang Sistem pengendalian Intern Pemerintah).

Dilihat secara atribusi, delegasi dan mandat, maka posisi Inspektorat Daerah sebagai lembaga pengawasan internal di pemerintah daerah sangat kuat, karena keberadaan lembaga ini dilindungi oleh undang-undang dan peraturan daerah. Jika dilihat dari jangkauan wilayah kerjanya (pengawasan) juga cukup luas karena wilayah yang diawasinya meliputi Sekretaris Daerah, (pejabat eselon IIa), ke samping semua Organisasi Perangkat Daerah (OPD) termasuk Sekretaris DPRD

13 Miftah Thoha, 2009, Birokrasi Pemerintah Indonesia di Era Reformasi, Kencana Prenada Media Group, Jakarta, hlm, 15.

14 Agus Dwiyanto, dkk, Op-Cit, hlm, 227. 
yang ada di daerahnya (pejabat eselon IIb setingkat dengan Inspektorat Daerah), dan ke bawah seluruh Camat dan seluruh Kepala Desa/Kelurahan yang ada di wilayahnya.

Pengaturan organisasi perangkat daerah yang begitu besar dan luas ini, yang menjadi jangkauan tugas dari lemabaga pengawasan internal (Inspektorat) daerah. Hal ini akan menjadi persoalan tersendiri bagi lembaga pengawasan internal tersebut, sebab kemampuan sumber daya manusia dan fasilitas penunjang lainnya sebagai sarana pendukung kinerja sangat terbatas. Persoalan lain yang menjadi kendala adalah keterbatasan kemampuan dan keberanian para auditor, inspektur dilingkungan Inspektorat untuk melakukan pengasawan terhadap atasannya sendiri (Kepala Daerah dan Sekretaris Daerah) mengingat status mereka adalah Pegawai Negeri Sipil Daerah yang posisinya berada di bawah kendali kepala daerah dan sekretaris daerah. Inspektur dan auditor internal ini diangkat dalam jabatan tersebut oleh kepala daerah. Sedangkan pembinaan teknis dalam melaksanakan tugasnya dilakukan oleh sekretaris daerah karena lembaga pengawasan (Inspektorat) adalah salah bagian dari Organisasi Perangkat Daerah (OPD). Oleh karena itu, maka perlu dilakukan penataan kembali tentang posisi lembaga pengawasan internal (Inspektorat) daerah ini dalam struktur organisasi pemerintahan daerah, agar di dalam melaksanakan tugas dan fungsinya dapat berjalan dengan baik tanpa adanya beban ketakutan pada pihak yang diawasinya dalam sebuah sistem dan mekanisme kerja yang baik, jelas, tegas, efektif dan efisien, yang akhirnya dapat tercipta penyeleng garaan pemerintahan daerah yang baik.

Oleh karena itu, dalam rangka terciptanya penyelenggaraan pemerintahan daerah yang baik diperlukan pengawasan internal yang memadai. Untuk mendapat kan suatu sistem pengawasan yang efektif, maka perlu dipenuhi dua prinsip pengawasan yaitu; pertama, adalah adanya rencana tertentu dan adanya pemberian instruksi-instruksi; kedua, pemberian wewenang yang jelas kepada bawahan. Prinsip kokok pertama merupakan satu keharusan, karena rencana itu merupakan standar, alat ukur dari pekerjaan yang dilaksanakan oleh bawahan. Rencana menjadi petunjuk apakah suatu pelaksanaan pekerjaan berhasil atau tidak. Prinsip pokok kedua wewenang merupakan suatu keharusan agar pelaksanaan pengawasan itu benar-benar dapat dilaksanakan secara efektif. Wewenang dan instruksi yang jelas harus dapat diberikan kepada bawahan karena berdasarkan itulah dapat diketahui apakah bawahan sudah menjalankan tugas-tugasnya dengan baik atau tidak.

George R. Terry mendefinisikan istilah pengawasan adalah "Control is to determine what is accomplished, evaluate $i t$, and apply corrective measures, if needed to ensure result in keeping with the plan." (Pengawasan adalah penentukan apa yang telah dicapai, mengevaluasi dan menerapkan tindakan korektif, jika perlu, memastikan hasil yang sesuai dengan rencana). ${ }^{15}$ Menurut Ikhwan Fahrojih dan Mokh Najih, bahwa secara umum pemeriksaan merupakan bagian dari pengawasan, sehingga melakukan fungsi pemeriksaan sekaligus juga berarti melakukan pengawasan. ${ }^{16}$

Pada umumnya dapat dikatakan, bahwa pengawasan terhadap segala kegiatan pemerintah daerah termasuk keputusan kepala daerah dan peraturan daerah, merupakan suatu akibat mutlak dari adanya negara kesatuan. Di dalam negara kesatuan kita tidak mengenal bagian yang lepas dari atau sejajar dengan negara, tidak

15 George R. Terry, 1986, Asas-asas Manajemen, diterjemahkan oleh Winardi, Alumni, Bandung, dan dikutip oleh Ni'matul Huda, hlm 22.

16 Ikhwan Fahrojih dan Mokh Najih, 2008, Menggugat Peran DPR dan BPK Dalam Reformasi Keuangan Negara, In-Trans Publishing, Malang, hlm 20 
pula mungkin ada negara di dalam negara. ${ }^{17}$ Sedangkan dalam kaitannya dengan keuangan negara pengawasan ditujukan untuk menghindari terjadinya "korupsi, peyelewengan, dan pemborosan anggaran negara yang tertuju pada aparatur atau pegawai negeri”. Dengan dijalankannya pengawasan tersebut diharapkan pengelola an dan pertanggung jawaban anggaran negara dapat berjalan sebagaimana direncanakan. ${ }^{18}$

Pada umumnya dapat dikatakan, bahwa pengawasan terhadap segala kegiatan pemerintah daerah termasuk keputusan kepala daerah dan peraturan daerah, merupakan suatu akibat mutlak dari adanya negara kesatuan. Di dalam negara kesatuan kita tidak mengenal bagian yang lepas dari atau sejajar dengan negara, tidak pula mungkin ada negara di dalam negara. ${ }^{19}$

Guna memperoleh suatu pengawas an yang efektif, maka perlu dipenuhi dua prinsip pengawasan yaitu; pertama, adalah adanya rencana tertentu dan adanya pemberian instruksi-instruksi; kedua, pemberian wewenang yang jelas kepada bawahan. Prinsip kokok pertama merupa kan satu keharusan, karena rencana itu merupakan standar, alat ukur dari pekerjaan yang dilaksanakan oleh bawahan.

Salah satu penyebab maraknya korupsi serta buruknya kinerja aparat pemerintahan daerah adalah karena lemahnya fungsi pengawasan terhadap penyelenggaraan pemerintahan daerah, baik fungsi pengawasan fungsional yang dilakukan oleh pemerintah pusat (Kementerian Dalam Negeri/Inspektorat Jenderal) maupun pengawasan internal yang dilakukan oleh Inspektorat Daerah

17 Ni'matul Huda, 2010, Hukum Pemerintahan Daerah, Nusa Media, Bandung, hlm 105.

18 Ahmad Fikri Hadin, 2013, Eksistensi Badan Pengawasan Keuangan dan Pembangunan di Era Otonomi Daerah, Genta Press, Yogyakarta, hlm, 22

19 Irawan Soejito, 1983, Pengawasan terhadap Peraturan Daerah dan Keputusan Kepala Daerah, Bina Aksara, Jakarta, hlm. 9.
(Provinsi, Kabupaten/Kota) sesuai dengan fungsi dan kewenangannya. Pengawasan yang dilakukan oleh Inspektorat daerah tidak optimal. Sistem peringatan dini (early warning system) yang seharusnya dilakukan oleh Inspektorat daerah di Provinsi maupun Kabupaten/Kota tidak berjalan dengan baik meski tugas mereka adalah menjadi mata dan telingan kepala daerah. (Kompas Rabu, 21 Juni 2017).

Pengawasan intern pemerintah merupakan fungsi manajemen yang penting dalam penyelenggaraan pemerintahan untuk mewujudkan kepemerintahan yang baik. Dalam rangka mewujudkan kepemerintahan yang baik, berdaya guna, berhasil guna, bersih dan bertanggung jawab diperlukan adanya Aparat Pengawasan Intern Pemerintah (APIP) yang berkualitas dan auditor yang profesional. Melalui pengawasan intern dapat diketahui apakah suatu instansi pemerintah telah melaksanakan kegiatan sesuai dengan tugas dan fungsinya secara efektif dan efisien, serta sesuai dengan rencana, kebijakan yang telah ditetapkan, dan ketentuan. (Standar Audit APIP, 2008)

Peraturan Pemerintah Nomor 60 Tahun 2008 tentang SPIP mengatur bahwa pengawasan internal terdiri dari lima komponen saling berhubungan. Komponen ini bersumber dari cara pimpinan suatu organisasi menyelenggarakan tugasnya dan oleh karena itu komponen ini menyatu dan terjalin dalam proses manajemen. Komponen tersebut adalah :

1. Lingkungan Pengendalian

2. Penilaian Resiko

3. Kegiatan Pengendalian

4. Informasi dan komunikasi

5. Pemantauan Pengendalian Intern

Memperhatikan luasnya ruang lingkup pengawasan dan menyangkut halhal yang fundamental terutama dalam hal penyelenggaraan pemerintahan daerah, maka diperlukan instrumen pelaksana yang kompatibel, aparatur pelaksana yang profesional, mampu, tanggap, mempunyai 
ketaatan serta mempunyai integritas dan reputasi yang teruji dalam menghadapi kompleksitas permasalahan dalam kegiatan pembinaan dan pengawasan.

Semua itu menuntut badan pengawas atau inspektorat untuk mampu dan memperkuat eksistensi dan kredibilitasnya baik secara kelembagaan ataupun perorangan kepada publik, karena di pundak merekalah kepercayaan publik diletakkan. Apalagi akhir-akhir ini banyak fakta yang menunjukkan meningkatnya tindak penyimpangan atau penyelewenang an dari para aparat ataupun lembaga sehingga menuntut Inspektorat untuk bisa meningkatkan kinerjanya. Oleh karenana, maka dipandang perlu memperkuat eksistensi Inspektorat dan keharusan untuk mengoptimalkan kinerjanya. Akan tetapi kinerja Inspektorat selama ini belum nenunjukkan kinerja yang optimal, pengawasan internal yang baik dan berdidikasi tinggi adalah salah satu kunci suksesnya penyelenggaraan Pemerintahan Daerah.

Pengawasan internal (Inspektorat) ini dibentuk dalam rangka agar pelaksanaan tugas pemerintahan daerah yang dijalankan oleh seluruh perangkat daerah yang ada dapat berjalan dengan baik, efektif, efisien berdaya guna dan tepat sasaran sesuai dengan rencana yang telah ditetapkan sebelumnya. Oleh karena itu peran Inspektorat dalam pengawasan jalannya tugas dari seluruh OPD yang ada di pemerintahan daerah ini sangatlah penting, agar kewenangan atau kekuasaan yang diberikan oleh undang-undang atau peraturan perundang-undangan lainnya dapat dijalankan dengan sebaik-baiknya oleh OPD, sehingga penyalahgunaan wewenang dalam menjalankan tugas dapat dihindari sedini mungkin.

Penyalahgunaan wewenang jabatan merupakan salah satu permasalahan yang sering terjadi di lembaga pemerintahan daerah, indikasi sering terjadinya penyalahgunaan wewenang ini terlihat masih banyaknya terjadi praktek Kolusi, Korupsi, dan Nepotisme (KKN). Banyaknya kasus korupsi yang terjadi akhir-akhir ini menjadikan perhatian besar bagi masyarakat. Masyarakat menuntut akan adanya transparansi dan akuntabilitas dalam pengelolaan keuangan oleh lembaga-lembaga sektor publik, diantaranya yaitu lembaga-lembaga pemerintah, perusahaan milik negara/daerah maupun organisasi publik lainnya yang ada di negeri ini. Tuntutan tersebut wajar dilakukan oleh masyarakat karena dalam berbagai penelitian yang dilakukan penyebab dari banyaknya penyelewangan wewenang yang terjadi tersebut disebabkan oleh pengelolaan pemerintah daerah yang buruk (bad governance) dan buruknya birokrasi yang ada di Indonesia ini. ${ }^{20}$

Pengawasan dan sistem pengendalian internal yang baik merupakan bagian dari fungsi manajemen, oleh karena itu perlu diterapkan agar tercipta sistem penyelenggaran pemerintahan yang bersih dan bebas dari KKN. Sehingga program kerja ataupun kebijakan yang telah disusun berjalan sesuai dengan rencana dan tujuannya penyelenggaraan permerintahan tercapai dengan baik, efektif, dan efisien. Oleh karena itu peran dan profesi auditor (Inspektorat) pemerintah daerah menjadi sorotan masyarakat dalam menjalankan tugasnya agar dapat dipercaya. Auditor harus melakukan penyempurnaan dalam hal pencapaian tujuannya agar dapat dipercaya oleh masyarakat. Selain itu juga, standar dan aturan etika profesi yang ada dilaksanakan dengan sebaiknya agar tercipta kualitas kerja yang baik oleh

20 Efendy, Muh. Taufiq, 2010. Pengaruh Kompetensi, Independensi, dan Motivasi terhadap Kualitas Audit Aparat Inspektorat dalam Pengawasan Keuangan Daerah (Studi Empiris pada Pemerintah Kota Gorontalo). Tesis. Program Studi Magister Sains Akuntansi Program Pascasarjana Universitas Diponegoro. Semarang. 
profesi auditor tersebut. ${ }^{21}$

Inspektorat Pemerintah Kabupaten/ Kota dinilai masih kurang optimal dalam pengawasan pengelolaan keuangan daerah. Penyimpangan anggaran dalam bentuk tindak pidana korupsi yang sering menjerat Kepala Daerah, Sekretaris Daerah Kepala Organisasi Perangkat Daerah (OPD), Camat sampai pada tingkat Kepala Desa/Lurah. Oleh karena itu, pemahaman tentang pentingnya auditor internal yang berkualitas dalam mewujudkan pemerintahan daerah yang baik dan akuntabel sangat diperlukan. Karena hal ini akan mampu memotivasi aparat inspektorat untuk menggunakan dan meningkatkan kompetensi dan independensi yang dimilikinya.

Salah satu unit yang melakukan audit / pemeriksaan terhadap pemerintah daerah adalah Inspektorat daerah. Inspektorat daerah mempunyai tugas menyelenggarakan kegiatan pengawasan umum pemerintah daerah dan tugas lain yang diberikan kepala daerah, sehingga dalam tugasnya Inspektorat sama dengan auditor internal. ${ }^{22}$

Peraturan Menteri Dalam Negeri Nomor 64 Tahun 2007 tentang Pedoman Teknis Organisasi dan Tata Kerja Inspektorat Provinsi dan Kabupaten/Kota. Dalam Pasal 4 menjelaskan bahwa dalam melaksanakan tugas pengawasan urusan pemerintahan, inspektorat provinsi, kabupaten/kota mempunyai fungsi yaitu perencanaan program pengawasan, perumusan kebijakan dan fasilitas pengawasan, dan pemeriksaan, pengusutan, pengujian, dan penilaian tugas pengawasan.

21 Noveri, Helsa. 2010. Pengaruh Pemahaman Good Governance dengan Independensi Auditor, Gaya Kepemimpinan, Budaya Organisasi Dengan Komitmen Organisasi sebagai Mediasi Terhadap Kinerja Auditor Internal, Tesis desertasi Universitas Andalas. Noveri, 2010

22 e-Journal S1 Ak Universitas Pendidikan Ganesha Jurusan Akuntansi Program S1 (Volume 2 No: 1 Tahun 2014)
Selain itu dengan adanya Peraturan Menteri Pendayagunaan Aparatur Negara dan Reformasi Birokrasi Nomor 15 Tahun 2009 tentang Jabatan Fungsional Pengawas Penyelenggaraan Urusan Pemerintahan di Daerah dan Angka Kreditnya, diharapkan dapat menjadi motivator bagi para aparatur pengawasan untuk lebih meningkatkan kinerjanya melalui peningkatan kualitas pengawasan.

Inspektorat daerah mempunyai tugas pokok melaksanakan pengawasan terhadap pelaksanaan urusan dan penyelenggaraan pemerintahan di daerah. Dalam kaitan tersebut Inspektorat tentunya terus menerus melakukan tindakan koreksi atas penyimpangan yang dilakukan terhadap pelaksanaan urusan dan penyelenggaraan pemerintahan di daerah apabila tidak sesuai dengan peraturan perundang-undangan yang berlaku. Paradigma Inspektorat saat ini adalah sebagai Quality Assurance atau penjamin mutu dan Consulting Partner atau sebagai konsultan maupun Early Warning System atau sebagai peringatan dini sebelum dilakukan pemeriksaan oleh eksternal, paradigmanya menjadi berubah yang tadinya sebagai pemeriksa saat ini lebih ditekankan melakukan pembinaan kepada seluruh Organisasi Perangkat Daerah (OPD). Hal tersebut sangat perlu dilakukan guna mewujudkan tata kelola pemerintahan yang baik serta terciptanya pemerintahan daerah yang baik, walaupun hasilnya belum optimal.

Untuk mewujudkan pengawasan yang efektif dan efisien pemerintah telah menerbitkan Peraturan Pemerintah terkait sistem pengawasan yaitu PP 79 Tahun 2005 tentang Pedoman Pembinaan Penyelenggaraan Pemerintah Daerah. Selanjutnya dilihat dari pengorganisasian kegiatan pengawasan di daerah diwadahi oleh suatu lembaga yang disebut Inspektorat yang ada ditingkat Provinsi dan Kabupaten/kota. Inspektorat Kabupaten mempunyai kewenangan untuk melakukan 
pengawasan terhadap pengelolaan keuangan desa, baik keuangan desa yang bersumber dari pendapatan asli desa maupun keuangan desa yang bersumber dari bantuan Pemerintah Pusat berupa Dana Desa, Dana Bantuan Keuangan yang bersumber dari Pemerintah Provinsi, maupun Alokasi Dana Desa (ADD) yang bersumber dari APBD Kabupaten.

\section{Kesimpulan}

Penyelenggaan pemerintahan daerah yang diatur oleh Undang-undang Nomor 23 Tahun 2014 mengandung tiga fungsi. Fungsi pertama adalah perencanaan kegiatan tugas pemerintahan daerah yang diakili oleh Badan Perencana Pembangun an Daerah (Bappeda), fungsi kedua adalah pelaksanaan kegaiatn tugas pemerintahan daerah yang diwakili dan dijalankan oleh Organisasi Perangkat Daerah (OPD) yang ada di pemerintah daerah, dan fungsi yang ketiga adalah pengawasan penyeleng garaan atau pelaksanaan pemerintahan daerah yang dilaksanakan oleh Inspektorat daerah sebagai pengawas internal pemerintahan daerah.

Pengaturan organisasi perangkat daerah yang begitu besar dan luas ini, yang menjadi jangkauan tugas dari lemabaga pengawasan internal (Inspektorat) daerah. Hal ini akan menjadi persoalan tersendiri bagi lembaga pengawasan internal tersebut, sebab kemampuan sumber daya manusia dan fasilitas penunjang lainnya sebagai sarana pendukung kinerja sangat terbatas. Persoalan lain yang menjadi kendala adalah keterbatasan kemampuan dan keberanian inspektur, para auditor, dilingkungan Inspektorat daerah untuk melakukan pengawasan terhadap atasannya sendiri (Sekretaris Daerah) mengingat status mereka adalah Pegawai Negeri Sipil Daerah yang posisinya berada di bawah kepala daerah dan sekretaris daerah. Inspektur dan auditor internal ini diangkat dalam jabatan tersebut oleh kepala daerah.
Sedangkan pembinaan teknis dalam melaksanakan tugasnya dilakukan oleh sekretaris daerah karena lembaga pengawasan internal (Inspektorat) adalah salah bagian dari Organisasi Perangkat Daerah (OPD). Oleh karena itu, maka perlu dilakukan penataan kembali tentang posisi lembaga pengawasan internal (Inspektorat) daerah ini, agar di dalam melaksanakan tugas dan fungsinya dapat berjalan dengan baik tanpa adanya rasa sungkan serta beban ketakutan pada pihak yang diawasinya dalam sebuah sistem dan mekanisme kerja yang baik, jelas, tegas dan efektif, agar penyelenggaraan pemerintahan daerah yang baik dapat terwujud.

\section{Saran}

Dalam rangka pelaksanaan tugas Inspektorat yang lebih independen dan kapabel, sebaiknya eselon Inspektorat itu disetarakan dengan Sekretaris Daerah yaitu IIa.

Proses pengisian jabatan inspektur, inspektur pembantu dan auditor dilakukan oleh Gubernur untuk Inspektorat Kabupaten / Kota dan oleh Menteri Dalam Negeri untuk Inspektorat Provinsi.

Keberadan Inspektorat tidak lagi sebagai bagian dari Organisasi Pearngkat Daerah, akan tetapi berada di bawah BPKP langsung sebagai bagian dari APIP dalam sistem pengawasan internal. Dengan demikian Inspektorat dalam melaksanakan tugasnya tidak bertanggung jawab kepada Kepala Daerah, akan tetapi bertanggung jawab langsung kepada Presiden melalui BPKP.

\section{DAFTAR PUSTAKA}

Agus Dwiyanto dkk, 2008, Reformasi Birokrasi Publik di Indonesia, Gadjah Mada Univercity Press, Yogyakarta.

Ahmad Fikri Hadin, 2013, Eksistensi Badan Pengawasan Keuangan dan Pembangunan di Era Otonomi 
Daerah, Genta Press, Yogyakarta.

Efendy, Muh. Taufiq, 2010. Pengaruh

Kompetensi, Independensi, dan Motivasi terhadap Kualitas Audit Aparat Inspektorat dalam Pengawasan Keuangan Daerah (Studi Empiris pada Pemerintah Kota Gorontalo).Tesis. Program Studi Magister Sains Akuntansi Program Pascasarjana Universitas Diponegoro. Semarang.

George R. Terry, 1986, Asas-asas Manajemen, diterjemahkan oleh Winardi, Alumni, Bandung.

Ikhwan Fahrojih dan Mokh Najih, 2008, Menggugat Peran DPR dan BPK Dalam Reformasi Keuangan Negara, In-Trans Publishing, Malang.

Irawan Soejito, 1983, Pengawasan terhadap Peraturan Daerah dan Keputusan Kepala Daerah, Bina Aksara, Jakarta.

J. Kaloh, 2003, Kepala Daerah, Pola Kegiatan, Kekuasaan Dan Perilaku Kepala Daerah Dalam Pelaksanaan Otonomi Daerah, Gramedia Pustaka Utama, Jakarta.

Joko Prihatmoko, 2005, Pemilihan Kepala Daerah Langsung, Filosofi, Sistem, dan Problema Penerapan di IndonesiaI, Pustaka Pelajar, Yogyakarta.

Lukman Santoso, Otonomi Yang Menyebarkan Korupsi, Jawa Pos 27 April 2011

Miftah Thoha, 2009, Birokrasi Pemerintah Indonesia di Era Reformasi, Kencana Prenada Media Group, Jakarta

Noveri, Helsa. 2010. Pengaruh Pemahaman Good Governance dengan Independensi Auditor, Gaya Kepemimpinan, Budaya Organisasi Dengan Komitmen Organisasi sebagai Mediasi Terhadap Kinerja Auditor Internal, Tesis desertasi Universitas Andalas, 2010.
Ni'matul Huda, 2010 , Hukum Pemerintahan Daerah, Cetakan Kedua, Nusa Media, Bandung.

Pranarka, 1996, Pemberdayaan BUMN, Erisco, Jakart

Saini dalam R. Cecep Eka Permana, 2010, Kearifan Lokal Masyarakat Baduy Dalam Mitigasi Bencana, Wedatama Widya Sastra, Jakarta.

Sarundajang, 2002, Pemerintahan Daerah di Berbagai Negara, Pustaka Sinar Harapan, Jakarta.

Sedarmayanti, 2003, Good Governant Dalam Rangka Otonomi Daerah, Mandar Maju, Bandung.

Syaukani H, 2003, Otonomi Daerah Dalam Negara Kesatuan, Pustaka Pelajar, Yogyakarta.

Peraturan Perundang-Undangan :

Undang-Undang Dasar Negara Republik Indonesia 1945.

Undang-Undang RI Nomor 32 Tahun 2004 Tentang Pemerintahan Daerah.

Undang-Undang RI Nomor 23 Tahun 2014 Tentang Pemerintahan Daerah.

Undang-Undang RI Nomor 28 Tahun 1999 Tentang Penyelenggaraan Negara Yang Bersih dan Bebas dari KKN.

Peraturan Pemerintah RI nomor 79 Tahun 2005 Tentang Pedoman Pembinaan dan Pengawasan Penyelenggaraan Pemerintah Daerah.

Peraturan Pemerintah Nomor 38 Tahun 2007 Tentang Pembagian Urusan Pemerintahan Antara Pemerintah, Pemerintahan Daerah Provinsi dan Pemerintahan Daerah Kabupaten / Kota

Peraturan Pemerintah Nomor 41 Tahun 2007 Tentang Organisasi Perangkat Daerah

Peraturan Pemerintah Nomor 60 Tahun 2008 Tentang Sistem pengendalian Intern Pemerintah

Peraturan Menteri Dalam Negeri Nomor 64 Tahun 2007 tentang Pedoman Teknis Organisasi dan Tata Kerja Inspektorat Provinsi dan Kabupaten/Kota. 
Johan Erwin Isharyanto : Pengelolaan Sumberdaya Perikanan Dalam Kerangka .....

Peraturan Menteri Pendayagunaan Aparatur Negara dan Reformasi Birokrasi Nomor 15 Tahun 2009 tentang Jabatan Fungsional Pengawas Penyelenggaraan Urusan Pemerintahan di Daerah dan Angka Kreditnya,
E-Journal S1 Ak Universitas Pendidikan Ganesha Jurusan Akuntansi Program S1 (Volume 2 No: 1 Tahun 2014) 